\title{
The Effect of Ramadan Fasting on the Kidney Function of Renal Transplant Recipients
}

\author{
Emhemed Ellafi Salem*, Ibrahim mohamed Akhili and Ahmed Bashir Akikli \\ Nephrology Department, Tajoura Heart Center, Tripoli, Libya
}

\begin{abstract}
Introduction: Fasting during the month of Ramadan, from dawn to sunset, is a religious obligation for healthy adult Moslems. Kidney transplant recipients are usually advised to liberalize fluid intake and are generally discouraged from fasting. However, stable kidney transplant recipients are often keen to fast Ramadan.
\end{abstract}

Methods: Twenty stable renal transplant recipients under regular follow-up at Tajoura Heart Center, Tripoli, Libya, voluntarily chose to fast during Ramadan (September 2008). Their physical and biochemical parameters were recorded on weekly basis, starting two weeks before and ending two weeks after Ramadan.

Results: Eleven males with a mean age of $41.7 \pm$ 9.8 years and nine females with a mean age of $44.9 \pm$ 12.3 years completed the follow-up period. They had a mean post-transplantation duration of 8.5 years, with a range of 1.5-26 years. All had normal graft function at the start of the study. Drug doses were taken just after sunset (breakfast) and before dawn (suhoor). None of them experienced any undue fatigue, dizziness or thirst compared to their experience of fasting before the onset of renal failure. Their body weight, blood pressure, cyclosporine level and urine volume were stable during the study period. There were no significant differences between mean serum levels of urea and creatinine and mean creatinine clearance measured two weeks prior to Ramadan, at the end of Ramadan, and two weeks after Ramadan among both male and female patients.

Conclusion: This study suggests that fasting during the month of Ramadan is safe for kidney transplant recipients with stable renal function.

\footnotetext{
* Corresponding author; Nephrology Department, Tajoura Heart Center, Tripoli, Libya; E mail: dremhemed@yahoo.com
}

Keywords: Fasting; Kidney Transplant Recipients; Ramadan

\section{The authors declared no conflict of interest}

\section{Introduction}

Ramadan fasting is one of the five pillars of Islam. Healthy adult Muslims of both genders are required to fast in the ninth month of each lunar year. Fasting Ramadan entails that the Muslim should refrain from eating and drinking from dawn to sunset. Daily activities are usually carried out with minor or no amendments. Eating and drinking are freely allowed from sunset to just before dawn of the next day. Exemption is given to the sick, travelers, debilitated elderly people and pregnant and lactating women. Several studies have concluded that fasting during Ramadan does not have any adverse effect on healthy adults [1-7].

Renal transplantation as a mode of treating end stage renal failure is now a well established form of therapy and virtually returns those patients to normality. Advice to kidney transplant recipients about fasting Ramadan has been controversial and the information on which to base this decision is sparse. Generally the advice tended to be against fasting, based on expedient reasoning. Over the last 10 years there has been a marked increase in renal transplants carried out on Moslem patients and the question of fasting has become more significant. Transplant recipients are usually advised to liberalize fluid intake and are generally discouraged from fasting. However, measurement of the concentrating ability of the transplanted kidneys has shown no difference from normal healthy individuals, a finding which perhaps argues against discouraging these patients from fasting Ramadan [8]. Indeed, many such patients who are advised not to fast do fast and in many cases have no adverse effects. In support of this notion there are several studies that suggest that fasting may not be as injurious in these patients as it was thought to be [9-16]. 
Table 1: Levels of serum urea and creatinine and creatinine clearance (mean \pm SD) of male patients throughout the study period

\begin{tabular}{lllll}
\hline & $\begin{array}{l}\text { Two weeks before } \\
\text { Ramadan }\end{array}$ & $\begin{array}{l}\text { At the end of } \\
\text { Ramadan }\end{array}$ & $\begin{array}{l}\text { Two weeks after } \\
\text { Ramadan }\end{array}$ & P value \\
\hline Serum urea $(\mathrm{mg} / \mathrm{dl})$ & $31.3 \pm 13.8$ & $37.8 \pm 07.8$ & $39.4 \pm 11.2$ & $>0.05$ \\
Serum creatinine $(\mathrm{mg} / \mathrm{dl})$ & $1.36 \pm 0.36$ & $1.10 \pm 0.23$ & $1.14 \pm 0.21$ & $>0.05$ \\
Creatinine clearance $(\mathrm{ml} / \mathrm{min})$ & $96 \pm 26$ & $100 \pm 17$ & $108 \pm 16$ & $>0.05$ \\
\hline
\end{tabular}

Table 2: Levels of serum urea and creatinine and creatinine clearance (mean \pm SD) of female patients throughout the study period

\begin{tabular}{lllll}
\hline & $\begin{array}{l}\text { Two weeks prior to } \\
\text { Ramadan }\end{array}$ & $\begin{array}{l}\text { At the end of } \\
\text { Ramadan }\end{array}$ & $\begin{array}{l}\text { Two weeks after } \\
\text { Ramadan }\end{array}$ & P value \\
\hline Serum urea $(\mathrm{mg} / \mathrm{dl})$ & $26.6 \pm 9.2$ & $34.7 \pm 7.8$ & $35.5 \pm 11.2$ & $>0.05$ \\
Serum creatinine $(\mathrm{mg} / \mathrm{dl})$ & $0.9 \pm 0.27$ & $0.8 \pm 0.23$ & $0.8 \pm 0.35$ & $>0.05$ \\
Creatinine clearance $(\mathrm{ml} / \mathrm{min})$ & $101.2 \pm 0.3$ & $114.7 \pm 0.6$ & $115.5 \pm 0.6$ & $>0.05$ \\
\hline
\end{tabular}

Adult Muslims who have received renal transplantation and are keen to practice their religion often ask their doctors whether fasting is safe. This study was undertaken to look for possible symptoms, signs and biochemical abnormalities in renal transplant recipients during Ramadan fasting.

\section{Methods}

Out of 100 renal transplant recipients on regular follow-up at the kidney department of Tajoura Heart Center, Tripoli, Libya, 25 patients voluntarily chose to fast during Ramadan (September 2008) and were included in this study. The study patients were advised to come for follow-up every week, starting two weeks ahead of Ramadan and continuing for two weeks after it. During each visit the patients' body weight, blood pressure and urine volume were measured, serum levels of urea, creatinine, and cyclosporine were determined and urine analysis for WBCs, RBCs and proteins was performed. In the four visits during Ramadan each patient was asked about undue fatigue, dizziness or thirst compared to his/ her previous experience.

\section{Results}

The study included 15 male transplant recipients with a mean age of 41.7 years (range 28-57 years, SD 9.8) and ten female transplant recipients with a mean age of 44.9 years (range 32-62 years, SD 12.3). Of these, four males and one female were later excluded from the study because of incomplete follow up.
Patients had a mean duration post-transplant of 8.5 years, with a range of 1.5-26 years, and all had normal graft function at the time of study. They were maintained on cyclosporine, azathioprine or mycophenolate mofetil, and prednisolone. Drug doses were taken just after sunset (breakfast) and before dawn (suhoor). Five patients were hypertensive; four patients were on nifedipine and atenolol and one patient was on diltiazem.

All patients completed the month of Ramadan, fasting every day from dawn to sunset. None of them experienced any undue fatigue, dizziness, thirst or any other symptom compared to their experience of fasting before the onset of renal failure. Their body weight, blood pressure, cyclosporine level and urine volume were stable during the study period.

There were no significant differences between mean serum levels of urea and creatinine and mean creatinine clearance measured two weeks prior to Ramadan, at the end of Ramadan, and two weeks after Ramadan among both male and female patients (Tables 1,2).

\section{Discussion}

Fasting during the month of Ramadan caused no adverse symptoms in the 20 renal transplant recipients studied, five of whom were also on anti-hypertensive treatment. In both male and female patients there was a consistent tendency of the serum creatinine to drop and the creatinine clearance to rise during and immediately after Ramadan, but this tendency did not reach statistical significance. There was also a slight increase in mean urea level compared to baseline that did not reach statistical 
significance. This rise in mean urea level may be due to reduction in fluid intake compared to non fasting days.

The absence of significant body weight change during fasting in this group of renal transplant recipients matches other reports of fasting kidney transplant recipients [10, 16]. However, there are reports of both weight loss as well as weight gain in fasting healthy adults in the literature $[2-4,6,8]$. These variations may be attributed to local traditions and food types consumed during the month of Ramadan.

The absence of significant changes in mean serum urea, creatinine and creatinine clearance before, during and after Ramadan fasting in this group of renal transplant recipients conforms with the results found in healthy individuals during fasting [17]. These results imply good functional abilities of the transplanted kidney. The rise in serum urea level during fasting has been reported in healthy fasters [18] as well and may be due to a common practice of not taking enough fluids after sunset.

A very useful and relevant study was conducted by Rashed et al in 43 transplant patients with stable renal functions. They showed that after a day-long fast these patients managed to concentrate their urine in a fashion similar to 23 healthy controls. Mean urinary osmolality recorded after the fast was 873 and 826 mosmol/ $\mathrm{kg}$ in healthy controls and transplant recipients respectively [8].

Stable graft function after Ramadan fasting was reported by a number of researchers [9-16]. Bernieh et al reported stable graft function in eleven kidney transplant recipients, eight of whom were also hypertensive. They observed a mild increase in potassium within normal range, attributed to increased intake of potassium containing diet during Ramadan. The fractional excretion of sodium was reduced during fasting indicating maintained ability of the kidney graft to conserve sodium [10].

Einollahi et al compared 19 kidney transplant recipients who voluntarily chose to fast during Ramadan with 20 matched recipients, who had not fasted for 3 years. They found no adverse effects of fasting in recipients with stable renal function. They concluded that fasting during the month of Ramadan is safe and has no significant harmful effects on kidney transplant recipients with normal renal function [13].

Our study shows that transplanted patients with stable graft function can fast the month of Ramadan safely without any serious adverse effects.

\section{Conclusion}

This study confirms that fasting during the month of Ramadan is safe for kidney transplant recipients with stable renal function and has no significant harmful effects on kidney graft function.

\section{References}

1. Mustafa KY, Mahmoud NA, Gumaa KA, Gader AM .The effects of fasting in Ramadan. 2. Fluid and electrolyte balance. Br J Nutr. 1978 Nov;40(3):583-9.

2. El Hazmi MAF, Al-Faleh FZ, Al-Mofleh IA. Effect of Ramadan fasting on the values of hematological and biochemical parameters. Saudi Med J. 1987;8:171-6.

3. Khogher Y, Sulaiman MI, Al-Fayez SF. Ramadan fasting and diabetes safety and state of control. Ann Saudi Med. 1987;7(Supp):6-7.

4. Suliman NA, Khatib FA. Effects of fasting Ramadan on body weight and some blood constituents of healthy Muslim. Nutr Rep Intern. 1988;38(6):1299-306.

5. Begma IA, Khan IH. Variations in ionic concentration of blood serum during Ramadan fasting. Pak J Sci. 1990;33:546-53.

6. Cheah SH, Ch'ng SL, Husain R, Duncan MT. Effects of fasting during Ramadan on urinary excretion in Malaysian Muslims. Br J Nutr. 1990 Mar;63(2):329-37.

7. Leiper JB, Molla AM, Molla AM. Effects on health of fluid restriction during fasting in Ramadan. Eur J Clin Nutr. 2003 Dec;57 Suppl 2:S30-8.

8. Rashed AH, Siddiqui SA, Abu Romeh SH, Hayden CT, Garcia-Buñuel L, Tang C, Rolfe M, Awad H. Clinical problems during fast of Ramadan. Lancet. 1989 Jun 17;333(8651):1396.

9. Rafi A, Al-Ahmed F, Al-Muhanna F, Al-Khursany I. Effect of Ramadan fasting on various biochemical and hematological parameters in renal transplant recipients. Saudi Kidney Dis Transplant Bull. 1993;4:S96.

10. Bernieh BO, Mohamed AO, Wafa AM. Ramadan fasting and renal transplant recipients: Clinical and biochemical effects. Saudi J Kidney Dis Transpl. 1994 October-December;5(4):470-3.

11. Al-Khader AA. Ramadan fasting and renal transplantation. Saudi J Kidney Dis Transpl. 1994 October-December;5(4):463-5.

12. Abdalla AH, Shaheen FA, Rassoul Z, Owda AK, Popovich WF, Mousa DH, al-Hawas F, al-Sulaiman $\mathrm{MH}$, al-Khader AA. Effect of Ramadan fasting on 
Moslem kidney transplant recipients. Am J Nephrol. 1998;18(2):101-4.

13. Einollahi B, Lessan-Pezeshki M, Simforoosh N, Nafar M, Pour-Reza-Gholi F, Firouzan A, Khatami MR, Nourbala MH, Pourfarzini V. Impact of Ramadan fasting on renal allograft function. Transplant Proc. 2005 Sep;37(7):3004-5.

14. Ghalib M, Qureshi J, Tamim H, Ghamdi G, Flaiw A, Hejaili F, Taher S, Katheri A, Shaheen F, Al-Khader AA. Does repeated Ramadan fasting adversely affect kidney function in renal transplant patients? Transplantation. 2008 Jan 15;85(1):141-4.

15. Einollahi B, Lessan-Pezeshki M, Pourfarziani V, Aghdam B, Rouzbeh J, Ghadiani MH, Nemati E.
Ramadan fasting in kidney transplant recipients with normal renal function and with mild to moderate renal dysfunction. Int Urol Nephrol. 2009;41(2):417-22.

16. Boobes Y, Bernieh B, Al Hakim MR. Fasting Ramadan in kidney transplant patients is safe. Saudi J Kidney Dis Transpl. 2009 Mar;20(2):198-200.

17. Cheah SH, Ch'ng SL, Husain R, Duncan MT. Effects of fasting during Ramadan on urinary excretion in Malaysian Muslims. Br J Nutr. 1990 Mar;63(2):329-37.

18. Roky R, Houti I, Moussamih S, Qotbi S, Aadil N. Physiological and chronobiological changes during Ramadan intermittent fasting. Ann Nutr Metab. 2004;48(4):296-303. 